\title{
Antibacterial Activity Testing on APMS ( $p$-Methoxy Cinnamic Acid) Against Escherichia coli Bacteria
}

\author{
Ahmad Fuad Masduqi ${ }^{1)}$, Erwin Indriyanti ${ }^{1)}$, Rahmawati Salsa Dinurrosifa ${ }^{1)}$ \\ 1)Program Studi Farmasi Sekolah Tinggi Ilmu Farmasi, Yayasan Pharmasi Semarang, Indonesia \\ Email: erwinindriyanti22@gmail.com
}

\begin{abstract}
This study aims to determine whether the compound APMS ( $p$-methoxy cinnamic acid) has the antibacterial activity of Escherichia coli and to determine the effective concentration of the compound APMS ( $p$-methoxy cinnamic acid) in inhibiting the growth of Escherichia coli bacteria. This research begins with the synthesis of APMS obtained through the knoevenagel condensation reaction with the sonochemical method. The synthesized compounds were tested organoleptically and their melting points were measured. The structure of the results was elucidated using FT-IR and GC-MS, then tested the antibacterial activity of APMS compounds against Escherichia coli. Data analysis with SPSS, 99\% confidence level $(\mathrm{p}<0.01)$ and continued with ANOVA test. The compound synthesized by APMS is in the form of fine crystals with a glossy white color, has a characteristic odor, and produces a $\%$ yield of $92.71 \%$. The level of $p$-methoxy cinnamic acid (APMS) produced from this study was $95 \%$ using the GC-MS Instrument. APMS compounds have antibacterial activity against Escherichia coli. The average inhibition zone formed at a concentration of $5 \% ; 10 \%$; and $15 \%$ respectively are $0.695 \mathrm{~cm} ; 0.727 \mathrm{~cm}$; and $0.855 \mathrm{~cm}$ The optimal concentration of this study was at a concentration of $15 \%$ which gave the greatest inhibition
\end{abstract}

Keywords: Antibacterial; Escherichia coli; $p$-Methoxy cinnamic acid

\section{Uji Aktivitas Antibakteri Senyawa APMS (Asam p_Metoksi Sinamat) Terhadap Bakteri Escherichia coli}

\begin{abstract}
ABSTRAK
Penelitian ini bertujuan untuk mengetahui apakah senyawa APMS (Asam p-metoksisinamat) memiliki aktivitas antibakteri Escherichia coli dan mengetahui konsentrasi efektif dari senyawa APMS (Asam p-metoksisinamat) dalam menghambat pertumbuhan bakteri Escherichia coli. Penelitian ini diawali dengan sintesis APMS ini didapatkan melalui reaksi kondensasi knoevenagel dengan metode sonokimia. Senyawa hasil sintesis diuji organoleptis dan diukur titik leburnya. Struktur hasil dielusidasi menggunakan FT-IR dan GC-MS, kemudian uji aktivitas antibakteri senyawa APMS terhadap Escherichia coli. Analisis data dengan SPSS, tingkat kepercayaan 99\% $(\mathrm{p}<0,01)$ dan dilanjutkan uji ANOVA. Senyawa hasil sintesis APMS berupa kristal halus berwarna putih mengkilap, memiliki bau khas, dan menghasilkan \% yield sebesar 92,71\%. Kadar Asam Para Metoksisinamat (APMS) yang dihasilkan dari penelitian ini sebesar 95\% menggunakan Instrumen GC-MS. Senyawa APMS memiliki aktivitas antibakteri terhadap Escherichia coli. Rataan zona hambat yang terbentuk pada konsentrasi 5\%; 10\%; dan $15 \%$ secara berturut adalah $0,695 \mathrm{~cm} ; 0,727$ $\mathrm{cm}$; dan $0,855 \mathrm{~cm}$ Konsentrasi yang optimal dari penelitian ini adalah pada konsentrasi $15 \%$ yang memberikan daya hambat yang paling besar.
\end{abstract}

Kata kunci: Antibakteri; Asam p-metoksi sinamat; Escherichia coli

(Article History: Received 30-08-2021; Accepted 08-10-2021; Published 09-10-2021)

\section{INTRODUCTION}

Cinnamic acid is a key intermediate in the shikimate and phenylpropanoid pathways (Indriyanti \& Prahasiwi, 2020). Shikimic acid is a precursor of many alkaloids, aromatic amino acids, and indole derivatives. It is found both in free form, and mainly in ester form (ethyl, cinnamon, benzyl), in various essential oils, resins and balsams, cinnamon oil, Peru balsam, and Tolu balsam, etc. It is a very important intermediate in most biosynthetic pathways (Sharma, 2011). Cinnamic acid has diverse bioactivity. This compound is can inhibit the growth of several species of bacteria and fungi (Guzman, 2014a). 
Cinnamate derivatives have very potential antimicrobial activity, this is due to the correlation between synthesis and physicochemical correlation and biological activity of a compound (Narasimhan et al., 2004). Studies on the antioxidant and antimicrobial properties of cinnamic acid and its derivatives have revealed the potential of this compound in pharmacological studies aimed at finding new antifungal drugs. Due to its low cytotoxicity, the inhibitory and antifungal properties of cinnamic acid derivatives are further explored in the food and cosmetic industry (Korošec et al., 2014).

The compound 4-methoxy cinnamic acid was isolated from the Argentine medicinal plant Baccharis grisebachii and its antimicrobial activity was evaluated. This acid exhibits strong antibacterial and antifungal effects. Interestingly, acid showed higher growth inhibition against fungal species compared to bacteria, and Gram-negative and Gram-positive bacteria were equally inhibited by the compound (Guzman, 2014b). 3,4methylenedioxycinnamic acid has been reported to inhibit Mycobacterium tuberculosis H37Rv with one report showing a MIC value of $312 \mu \mathrm{M}$ and the other a MIC value higher than $520 \mu \mathrm{M}$ (Sova, 2012).

APMS compounds can also be produced from the hydrolysis of EPMS (ethyl para methoxy cinnamate) isolated from the kencur plant (Silalahi, 2019) (Hidajati \& Suyatno, 2008). One of the cinnamic derivatives is a compound synthesized between anisaldehyde, malonic acid, -alanine, and pyridine through knoevenagel condensation to produce APMS ( $p$-methoxy cinnamic acid) (Chiriac et al., 2009). The compound $p$-methoxy cinnamic acid is a derivative compound of cinnamic acid which is substituted for a methoxy group at the para position (Guzman, 2014a). P-methoxy cinnamic acid is known to be a compound that functions as an analgesic, anti-inflammatory, and antimicrobial (Ekowati et al., 2010) antioxidant, antidiabetic, and hepatoprotective, neuroprotective, and chemopreventive activity (Lipase et al., 2020).

The purpose of this study was to determine whether the compound APMS ( $p$ methoxy cinnamic acid) had antibacterial activity against Escherichia coli and to determine the effective concentration of the compound APMS in inhibiting the growth of Escherichia coli bacteria.

Based on this background, this study was conducted to determine the bioactivity of the compound APMS ( $p$-methoxy cinnamic acid) against Escherichia coli bacteria.

\section{RESEARCH METHODS}

\section{a. Place and time of research}

This research was carried out at the Stifar Laboratory of the Pharmacy Foundation Semarang in March-July 2021. The procedures in this study included the preparation of the compound APMS ( $p$ methoxy cinnamic acid), testing the synthesized compound, and testing the antibacterial activity of the synthesized compound against Escherichia coli bacteria.

\section{b. Materials}

The materials used in this study were $\mathrm{p}$ anisaldehyde (pa, Sigma-Aldrich), malonic acid (pa, Merck), -alanine (pa, Merck), pyridine (pa, Merck), $\mathrm{NaHCO}_{3}$ (pa, Merck), aquadest, hydrochloric acid (pa, Merck), diethyl ether (pa, Merck), ethanol (pa)., DMSO, Nutrient Agar, Nutrient Brooth, Mannitol Salt Agar, aquadest, and Escherichia coli.

\section{Synthesis of APMS ( $p$ - Methoxycinnamic Acid)}

This APMS synthesis used a procedure based on Verley-Dobner (Hoai et al., 2018) with slight modifications. A total of 6.61 mmol anisaldehyde, $16.8 \mathrm{mmol}$ malonic acids, and $1.12 \mathrm{mmol}$-alanine were dissolved in 37.1 mmol pyridines in an Erlenmeyer flask. The solution was covered with aluminum foil, then sonicated for 60 minutes at $60^{\circ} \mathrm{C}$. After that, it was cooled to room temperature in an ice bath, then $8 \mathrm{~mL}$ of $\mathrm{HCl}$ was added slowly until a white precipitate was formed. The APMS solids were filtered with a vacuum pump and rinsed with cold distilled water. The solid obtained was recrystallized using a mixture of distilled water: ethanol (3:1). The crystals formed are then dried in an oven to dry. After drying, the crystals were weighed and yields were calculated, then the synthesized compounds were tested for melting point, solubility, FTIR-ATR, and GC-MS spectrophotometers. 


\section{Inoculum Preparation}

This study uses the procedure as carried out by Ernawati, et al (Ernawati et al., 2016) with slight modifications. The culture stock of Escherichia coli bacteria that has been rejuvenated and grown is taken using a sterile ose needle and then suspended into a tube containing $10 \mathrm{~mL}$ of sterile distilled water, until the turbidity is obtained according to the standard Mc. Farland turbidity, the concentration of the bacterial suspension is around $10^{8} \mathrm{CFU} / \mathrm{mL}$. After that, dilution was carried out to obtain a concentration of bacterial suspension of $10^{6} \mathrm{CFU} / \mathrm{mL}$ by pipetting $2.0 \mathrm{~mL}$ of suspension $\left(10^{8} \mathrm{CFU} / \mathrm{mL}\right)$ added to a tube containing $8 \mathrm{~mL}$ of sterile distilled water. This suspension will be used for antibacterial testing.

\section{Preparation of Test Solutions with Various Concentrations}

The cinnamate derivative used is APMS. This APMS was synthesized in our laboratory and its compounds have been identified using spectroscopic tools (GCMS, FTIR). Each sample was made with a concentration of $5 \%, 10 \%$, and $15 \%$ which will be used for antibacterial testing. Samples with a concentration of $5 \%$ were made by weighing 0.25 grams of APMS and dissolved with $5 \mathrm{~mL}$ of DMSO, samples with a concentration of $10 \%$ weighed 0.5 grams and dissolved with $5 \mathrm{~mL}$ of DMSO, and samples with a concentration of $15 \%$ were made by weighing 0.75 gram and dissolved in $5 \mathrm{~mL}$ DMSO.

\section{In Vitro Antibacterial Testing}

Antibacterial activity test was carried out using the good method. APMS samples were made with concentrations of $5 \%, 10 \%$, and $15 \%$. Negative control using DMSO and positive control using ciprofloxacin. Replication 8 times. Then it was incubated at a temperature of $37^{\circ} \mathrm{C}$ for 24 hours and then seen the presence of a clear area/the effect of inhibition on bacterial growth in the area around the well and measured using a caliper.

\section{Data analysis}

The data obtained were then analyzed using the Analysis Of Variance (ANOVA) method with a significance level of $5 \%$. Data analysis was calculated with the help of a computer program SPSS for windows version 23.

\section{RESULTS AND DISCUSSION}

The preparation of the compound $p$ methoxy cinnamic acid refers to VerleyDoebner with a slight modification by going through a knoevenagel condensation reaction between anisaldehyde, malonic acid, and alanine using a pyridine catalyst (Hoai et al., 2018). Through the ultrasonic wave-assisted sonochemical method (Ghomi \& Akbarzadeh, 2018). Knoevenagel condensation uses malonic ester, malonic acid, or acetic acid as a substitute for malonic anhydride to produce good results from cinnamic acid derivatives with electron donor substituents at the para position in the aromatic ring (Hoai et al., 2018). The use of malonic acid and -alanine and the presence of pyridine as a catalyst show great potential in the manufacture of cinnamic acid derivatives (Hoai et al., 2018). The use of pyridine as an organic base catalyst is a tertiary aromatic amine with sp2 hybridization, the lone pair of pyridine nitrogen electrons are more attracted to the aromatic ring so that its basicity and nucleophilicity are rather low (Ekowati et al., 2010).

The use of ultrasonic waves in organic synthesis has become an option in recent years. The sonochemical effect is a cavity. Ultrasonic waves occur at a frequency of 20 $\mathrm{kHz}$ to $100 \mathrm{MHz}$. Ultrasonic waves are known to accelerate various types of organic reactions and are believed to be an important technique in organic synthesis (Ghomi \& Akbarzadeh, 2018) Sonochemistry offers short reaction times and high yields in the synthesis of organic compounds (Babu et al., 2013), environmentally friendly because it minimizes waste and minimizes energy use (Patel et al., 2014).

The results of the organoleptic test showed that the synthesized compound was in the form of fine, shiny white crystals with a characteristic odor. When compared with the standard p-Methoxycinnamic Acid, the synthesized compound has the same melting point, which is $172^{\circ} \mathrm{C}$ (Syarifatul, 2014). The results of the structural elucidation test using FT-IR spectrophotometry can be seen in Figure 1. 


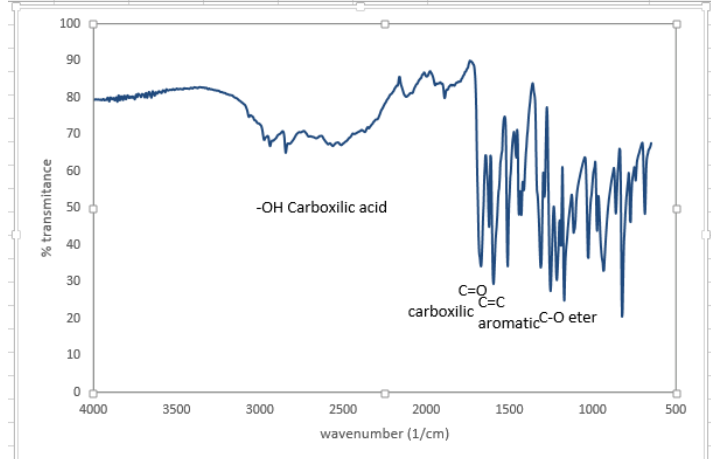

Figure 1. The IR Spectrum Of The APMS Compound

In Infrared spectra of the synthesized $p$ methoxy cinnamic acid compound, there are several fingerprint bands indicate the groups contained in the structure of the synthesized compound. Figure 2 shows the width of the $\mathrm{O}$ $\mathrm{H}$ bond of the carboxylic acid compound $p$ methoxy cinnamic acid at $2531 \mathrm{~cm}-1,2538$ $\mathrm{cm}^{-1}$, and $2542 \mathrm{~cm}^{-1}$. Wave numbers $842 \mathrm{~cm}^{-1}$ and $836 \mathrm{~cm}^{-1}$ indicate the presence of an Aromatic group substituted at the para position which is a fingerprint that has a wavenumber theory above $800 \mathrm{~cm}^{-1}$ (Sastrohamidjojo, 1991). Wave numbers 2531 $\mathrm{cm}^{-1}, 2538 \mathrm{~cm}^{-1}$, and $2542 \mathrm{~cm}^{-1}$ indicate the presence of a wide O-H Carboxyl group with a theoretical range of $3400-2400 \mathrm{~cm}^{-1}$ (Sastrohamidjojo, 1991). The wavenumber of $1674 \mathrm{~cm}^{-1}$ is close to the research (Mumpuni et al., 2010) which is $1685 \mathrm{~cm}^{-1}$. The wavenumber of $1513 \mathrm{~cm}-1$ indicates the presence of an aromatic $\mathrm{C}=\mathrm{C}$ group with a theoretical range of $1600-1475 \mathrm{~cm}^{-1}$. Wavenumber $1599 \mathrm{~cm}^{-1}$ indicates the presence of an aromatic group.

The characterization of $p$ - methoxy cinnamic acid using the GC-MS instrument was carried out with the aim to ensure the presence of the target compound in the synthesized product. The chromatogram of APMS compounds can be seen in Figure 2.

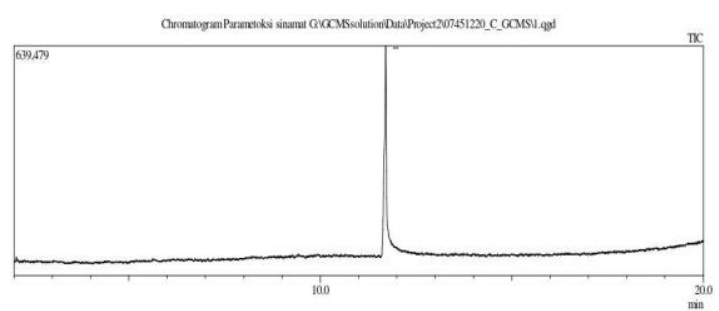

Figure 2. Chromatogram of APMS Compounds

Based on Figure 2, it is known that the synthesized compound contains one compound which is indicated by the presence of one peak. Mass spectra patterns were compared with library searches. The peak with a retention time of 11,710 minutes had a compound abundance of $100 \%$. The mass spectra pattern in Figure 4 is similar to that of the $p$-methoxy cinnamic acid compound library, which has a molecular weight of $178.18 \mathrm{~g} / \mathrm{mol}$. The peak with the $\mathrm{m} / \mathrm{z}$ value of 178 is the base peak.

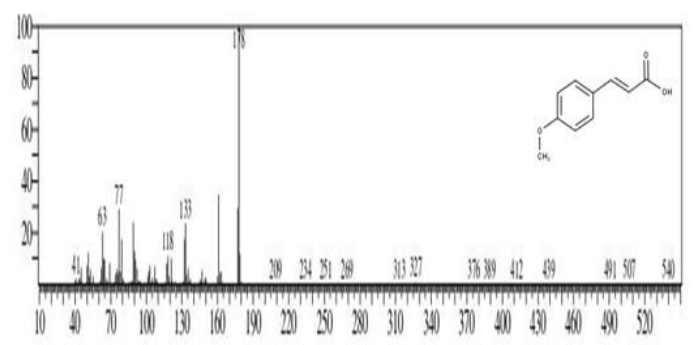

Figure 3. Mass Spectra of APMS Compounds

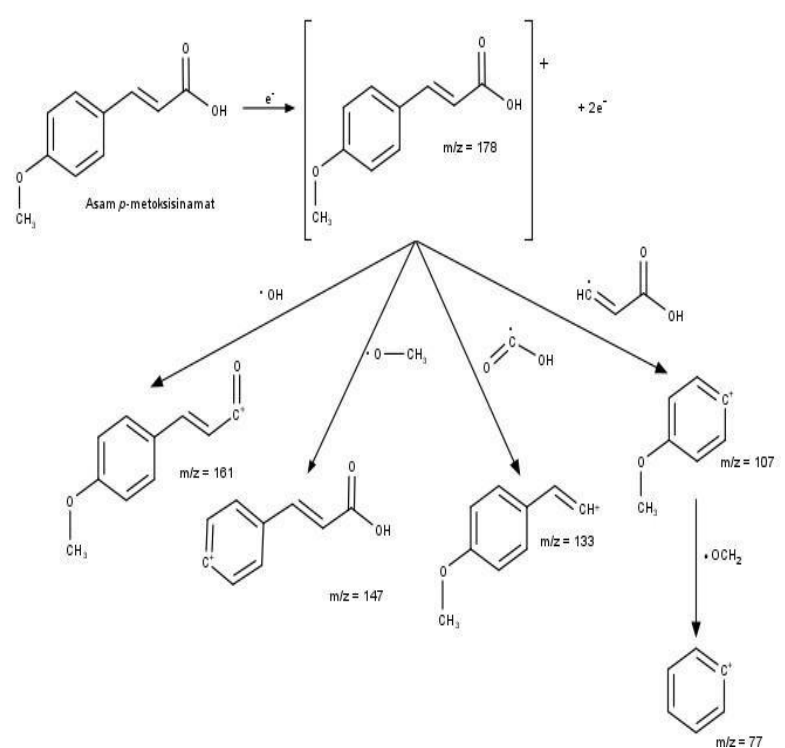

Figure 4. Fragmentation Pattern of APMS Compounds

Based on Figure 3 and 4 it can be explained that the first fragmentation pattern, molecular ions releasing $\mathrm{OH}$ radicals produces a peak with a value of $\mathrm{m} / \mathrm{z} 161$. In the second fragmentation pattern, molecules releasing methoxy radical ions produce a peak with a value of $\mathrm{m} / \mathrm{z} 147$. In the third fragmentation pattern, molecules releasing $\mathrm{COOH}$ radical ions produce a peak with a value of $\mathrm{m} / \mathrm{z} 133$. In the fourth fragmentation pattern, the molecular ion releases propenoic acid radicals produce a peak with an $\mathrm{m} / \mathrm{z}$ value of 107 . As well as the fifth fragmentation pattern, the molecular ion releases methoxide radicals leaving a benzene structure with an $\mathrm{m} / \mathrm{z}$ value 
of 77. Based on the molecular fragmentation process by looking at the results of the fragments formed, it shows that the compound that was synthesized is $p$-methoxy cinnamic acid.

One of the compounds from cinnamic acid derivatives, some of these cinnamic acid derivatives have various biological activities such as antibacterial, anesthetic, antiinflammatory, antispasmodic, antimutagenic fungicidal, herbicide, and tyrosinase enzyme inhibitor (Septian et al., 2012). The results of the antibacterial activity test of APMS compounds against Escherichia coli bacteria can be seen in Table 1.

Table 1. APMS Data Against E. coli bacteria

\begin{tabular}{cccccc}
\hline Replikasi & \multicolumn{5}{c}{ Diameter Zona Hambat (cm) } \\
\cline { 2 - 6 } & APMS & APMS & APMS & K(-) & K(+) \\
& $\mathbf{5 \%}$ & $\mathbf{1 0 \%}$ & $\mathbf{1 5 \%}$ & & \\
\hline 1 & 0,700 & 0,640 & 0,905 & 0,000 & 2,110 \\
2 & 0,548 & 0,543 & 0,608 & 0,000 & 2,300 \\
3 & 0,718 & 0,765 & 0,898 & 0,000 & 2,703 \\
4 & 0,805 & 0,938 & 0,980 & 0,000 & 3,002 \\
5 & 0,658 & 0,760 & 0,825 & 0,000 & 3,190 \\
6 & 0,725 & 0,523 & 0,828 & 0,000 & 2,613 \\
7 & 0,603 & 0,868 & 0,900 & 0,000 & 2,685 \\
8 & 0,775 & 0,780 & 0,903 & 0,000 & 2,860 \\
\hline
\end{tabular}

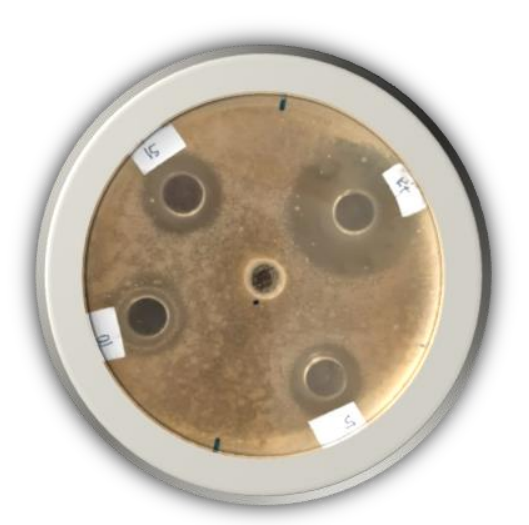

Figure 5. APMS Activity Test against E. coli Bacteria

Based on Figure 5 the results showed that the compound $p$-methoxy cinnamic acid (APMS) had antibacterial activity against Escherichia coli bacteria. This can be seen from the diameter of the inhibition/clear zone around the well at all test concentrations. The average diameter of the inhibition zone formed at a concentration of $5 \% ; 10 \%$; and $15 \%$ respectively are $0.691 \mathrm{~cm} ; 0.727 \mathrm{~cm}$; and $0.855 \mathrm{~cm}$. The negative control using DMSO resulted in $0 \mathrm{~cm}$, while the positive control used ciprofloxacin with an inhibition zone diameter of $2.682 \mathrm{~cm}$.

The greater the concentration, the greater the diameter of the inhibition zone.
This indicates that the greater the tested APMS compound, the greater the antibacterial activity against $E$. coli bacteria.

The results of data analysis using SPSS and continued with the ANOVA test showed that the tested concentration of E. coli was 5\%; $10 \%$; and $15 \%$ obtained significantly different results $(\mathrm{p}<0.01)$.

\section{CONCLUSION}

The level of $p$-Methoxycinnamic Acid (APMS) produced from this study was $100 \%$ using the GC-MS Instrument. APMS compounds have antibacterial activity against Escherichia coli. The average inhibition zone formed at a concentration of $5 \% ; 10 \%$; and $15 \%$ respectively are $0.695 \mathrm{~cm} ; 0.727 \mathrm{~cm}$; and $0.855 \mathrm{~cm}$ The optimal concentration of this study was at a concentration of $15 \%$ which gave the greatest inhibition.

\section{ACKNOWLEDGEMENT}

Thank you to the Pharmacy Foundation and LPPM STIFAR Semarang Pharmacy Foundation who have provided funding for this research, along with the parties involved and who have formed this research.

\section{REFERENCES}

Babu, P.N.K., Devi, B.R. \& Dubey, P.K. 2013. Ultrasound assisted convenient, rapid and environmentally benign synthesis of $\mathrm{N}$-alkylbenzimidazoles. Der Chemica Sinica, 4(1):105-110.

Chiriac, C.I., Tanasa, F. \& Nechifor, M. 2009. A novel direct boron-mediated synthesis of cinnamic acids from aromatic aldehydes and aliphatic carboxylic acids. Revue Roumaine de Chimie, 54(11-12):987-991.

Ekowati, J., Astika, W.D.N. \& Budiati, T. 2010. Pengaruh Katalis pada Sintesis Asam O-Metoksisinamat dengan Material Awal O-Metoksi Bezaldehide dan Uji Aktivitas Analgesiknya. Majalah Farmasi Irlangga, 8(2). 
Ernawati, T., Budiana, A. \& Ernawati, T. 2016. Bioaktivitas Turunan Metil Sinamat Terhadap Pertumbuhan Bakteri Escherichia coli, Staphylococcus aureus, Bacillus subtilis, Pseudomonas aureugenosa dan Jamur Candida albicans. Jurnal Kimia VALENSI, 1(1):60-64. https://doi.org/10.15408/jkv.v0i0.3154.

Ghomi, J.S. \& Akbarzadeh, Z. 2018. Ultrasonic accelerated Knoevenagel condensation by magnetically recoverable $\mathrm{MgFe} 2 \mathrm{O} 4$ nanocatalyst: $\mathrm{A}$ rapid and green synthesis of coumarins under solvent-free conditions. Ultrasonics Sonochemistry, 40:78-83. https://doi.org/10.1016/j.ultsonch.2017 .06.022.

Guzman, J.D. 2014a. Natural cinnamic acids, synthetic derivatives and hybrids with antimicrobial activity. Molecules. https://doi.org/10.3390/molecules 1912 19292.

Guzman, J.D. 2014b. Natural cinnamic acids, synthetic derivatives and hybrids with antimicrobial activity. Molecules, 19: 19292-19349. https://doi.org/10.3390/ molecules 191219292.

Hidajati, N. \& Suyatno. 2008. Sintesis Senyawa Tabir Matahari n-Oktil ParaMetoksi Sinamat Menggunakan Material Awal Etil Para-Metoksi Sinamat Hasil Isolasi dari Rimpang Kencur (Kaemferia galanga L .) Synthesis of a Sunscreen Compound nOctyl Para-Menthoxy Cinnamat using Ethyl Para-M. Jurnal Ilmu Dasar, 9(1):22-27.

Hoai, N.T., Ngoc, T.T.Y., Nam, N.D., Thuy, T.T., Trang, C.T.T., Hai, N.D. \& Nguyen, T.K. 2018. Effect of $\beta$-alanine on the preparation of 4-ethoxycinnamic acid. Open Materials Science Journal, 12(1):58-67. https://doi.org/ 10.2174/1874088X01812010058.

Indriyanti, E. \& Prahasiwi, M.S. 2020. Synthesis of cinnamic acid based on perkin reaction using sonochemical method and its potential photoprotective agent. 5(1):54-61.
Korošec, B., Sova, M., Turk, S., Kraševec, N., Novak, M., Lah, L. \& Komel, R. 2014. Antifungal activity of cinnamic acid derivatives involves inhibition of benzoate 4-hydroxylase (CYP53). Journal of Applied Microbiology, 116(4):955-966. https://doi.org/10. 1111/jam.12417.

Lipase, I., Candida, B., Rychlicka, M. \& Gliszczy, A. 2020. With pMethoxycinnamic Acid Catalyzed by.

Narasimhan, B., Belsare, D., Pharande, D., Mourya, V. \& Dhake, A. 2004. Esters, amides and substituted derivatives of cinnamic acid: Synthesis, antimicrobial activity and QSAR investigations. European Journal of Medicinal Chemistry, 39(10):827-834. https://doi. org/10.1016/j.ejmech.2004.06.013.

Patel, B.R., Desai, D.H. \& Raval, J.P. 2014. Green Efficient Synthesis of Aryl Thioamides Using Ultrasound: A Comparative Study. Journal of Pharmacy And Applied Sciences, 1(1):29-33.

Septian, A.N., Kusoro, S. \& Sudarmin. 2012. Abstrak Abstract. Uji Antimikroba Etil P-Metoksi Sinamat Dari Rimpang Krncur Terhadap Bacillus Subtilis, 1(2252):98-103. https://doi.org/10. 14710/teknik.v37n2.9011.

Sharma, P. 2011. Cinnamic acid derivatives: A new chapter of various pharmacological activities. Journal of Chemical and Pharmaceutical Research, 3(2):403-423.

Silalahi, M. 2019. Kencur (Kaempferia galanga) dan bioaktivitasnya. Jurnal Pendidikan Informatika Dan Sains, 8(1):127. https://doi.org/10.31571/ saintek.v8i1.1178.

Sova, M. 2012. Antioxidant and Antimicrobial Activities of Cinnamic Acid Derivatives. Mini-Reviews in Medicinal Chemistry. https://doi.org /10.2174/138955712801264792

Syarifatul, M. 2014. Modifikasi Struktur Senyawa Etil p-metoksisinamat yang Diisolasi dari Kencur (Kaempferia galanga Linn.) Melalui Transformasi Gugus Fungsi Serta Uji Aktivitas Sebagai Antiinflamasi [Skripsi]. UIN Syarif Hidayatullah, Jakarta. 